\title{
Treasure Hunt in the Library: An Exercise in Academic Literacy
}

\author{
Dorothy Langley \\ Department of Instructional Systems' Technologies, \\ Holon Institute of Technology, Holon, Israel
}

\author{
Langley@hit.ac.il
}

\begin{abstract}
This paper presents an Academic Literacy course designed for first year students in our department. The course is based on a set of relevant reading materials and covers knowledge levels and classification systems, logical and physical library organization principles, physical and virtual search for publications, bibliographic citations and referencing methods and purposes.

The paper describes two, out-of-class, activities related to the academic and public libraries in the information age. The first activity, the "Book Hunt", organizes the students' conceptions of the variety of functions being served and the impact of information technology on retrieving academic publications. Students' response to a reflective assignment dealing with concepts and impressions is described. The second activity "Visiting a public library", involves interviewing the librarian and writing a report on the structure and functions of the library. The paper discusses features of students' reports and indicates the contribution of the activities to the students' academic world view.
\end{abstract}

Keywords: Academic literacy, out-of-class activity, library, knowledge classification, librarian, information age.

\section{Introduction - Course Overview}

A course in Academic Literacy is a requirement for first year arts and social science college students. The course is intended to promote acculturation into academic life and literature and to guide students as they acquire skills of reading and comprehending academic publications and writing in an appropriate style. The reading material and the writing assignments should be selected so as to best enhance the students' capabilities to perform well in their major courses.

The reading material and assignments for students in the department of Instructional Systems' Technologies was selected by consulting lecturers in the other first year courses and obtaining examples of papers that could contribute to understanding in their courses and which they would

Material published as part of this publication, either on-line or in print, is copyrighted by the Informing Science Institute. Permission to make digital or paper copy of part or all of these works for personal or classroom use is granted without fee provided that the copies are not made or distributed for profit or commercial advantage AND that copies 1) bear this notice in full and 2) give the full citation on the first page. It is permissible to abstract these works so long as credit is given. To copy in all other cases or to republish or to post on a server or to redistribute to lists requires specific permission and payment of a fee. Contact Publisher@InformingScience.org to request redistribution permission. not be able to deal with in the normal run of events. To these I have added publications that provide a cohesive context for the different papers.

The course starts with a short quiz dealing with factual knowledge about the invention of the printing press, the sections of a research paper, the cost of a subscription to a journal, how long it takes a paper to get published, the num- 
ber of journals published by large publishers, and rights and regulations using web resources. The students' responses reveal considerable ignorance which provides a rationale for the course content.

We start with "It's a Fact" - chapter 4 in "The Day the Universe Changed" (Burke ,1973), centered around the invention of the printing press and its impact on culture, politics, economy and education. The students learn to see the printing press as an information technology, freeing mankind from the need to store knowledge in biological memory systems and heralding the advent of the information age with the universal accessibility of reliable sources of knowledge and know-how and potential for exchange of ideas and information. This is a relatively easy text to read as it is written in a popular scientific style and includes pictorial illustrations.

Our next reading selection is "Society of the Future and the Desired Graduate" - chapter 2 in "Education in the Technology Era" (Solomon, 1992). In this chapter the students learn about characteristics of the evolving society and the types of knowledge, skills and intellectual dispositions that are required to function successfully within it.

The style of this chapter is more scholarly, using erudite terms from the fields of psychology, sociology and education and developing arguments based on logical reasoning. Thus, this chapter provides a context for exploring the characteristics of the form and content of academic writing, and drawing attention to the method of citing sources and writing references.

The reading material for the rest of the course includes several paper types:

“Knowledge Organization” papers dealing with Digital literacy (Eshet, 2000), Information- interaction design (Shedroff, 1994) and types of interactivity (Sims, 1995).

Research papers dealing with simulations in early science education (Henderson, Klemes, \& Eshet, 2000) and concept-mapping as a research tool (Pearson \& Somekh, 2003).

"Tools and methods" papers dealing with addressing students' common difficulties in basic electricity (Ronen \& Eliahu, 1997).

We devote a session to methods of citing sources and writing references, mainly following the APA style. The students are required to identify and select references of different types of publications (e.g. monographs, chapters in edited books, papers in scholarly journals, web sources) from the bibliographies in their reading material. This seemingly technical activity is not only an important academic writing skill, but it also draws the students' attention to the bibliography which holds revealing information about the sources the authors chose to cite.

Quite early in the course we discuss levels of knowledge (data, information, knowledge and wisdom) and classification systems of knowledge domains such as the Dewey Decimal Classification, and conclude that the Universal Decimal Classification (which is used in our institute's library) is more appropriate in an era in which new knowledge domains are created and traditional ones converge into multi- and inter- disciplinary domains.

A display of books and journals brought to class, covering topics such as cognitive psychology, instructional technology, visual communication and research in social sciences helps the students become acquainted with the different types of academic publications and the variety of journals dealing with different areas of relevant domains of knowledge. Leafing through academic publications (in English) is a novel experience for our students and prepares them for the library visit.

\section{"Book Hunt" in the Library}

Once the foundations for an informed world view of academic publications have been laid, our next step is to become acquainted with searching and retrieving publications physically and virtu- 
ally. To this end we hold our fifth session of the course in the library. The librarian in charge of counseling guides the students around the library, pointing out the physical arrangement principles, such as grouping textbooks by author name, rather than by UDC classification, and grouping and dividing knowledge domains in different areas, rather than sequentially, owing to constraints on space or according to the level of reader activity. During this guided tour the students become aware of the different functions served by the library staff, according to qualifications and experience.

After the tour the students gather in a lecture area, where the library online catalogue is introduced, methods of finding and retrieving a particular book or journal are explained, as well as how to find out whether a book is on loan, how many copies exist, whether the book is considered a "textbook" or not, and how to place an order or request an extension of a loan of a book. The students are also shown the interconnectivity of academic libraries all over the country and the ability to search the inter-library space for a certain book or journal.

This session culminates in an enthusiastic "book hunt" in which teams of 2-3 students receive "missions" to search for and bring to a central place a dozen varied academic publications. The list includes books and journals dealing with almost all the topics the students encounter in their other courses. The students set out with great enthusiasm and the librarian helps them complete their missions when necessary. The retrieved books and journals are brought back to the lecture area and displayed on a table to create an integrated impression of up-to-date, high quality publications in relevant fields.

\section{Student Impressions}

Following the "Book Hunt", students are given an assignment summing up their library experience. Following are the assignment details and examples of student responses.

\section{List 5 concepts related to the library}

Students included a variety of concepts, adding explanations and examples. The list of concepts included:

- academic literacy concepts they had already learnt such as: literacy, discipline (domain of knowledge), academic publication, journal, scholarly research paper, classification system, cultural world view, logical/ physical organization, UDC, DDC

- specific concepts of library organization and terms related to the library web-site that they had first met during the visit, such as: system number, [book] collection, guided experience, electronic library, constraints, informatics, information banks, reserved book, textbook, book of reference, catalog, title, reader file, holdings.

\section{Describe your impressions of the visit from the cognitive, social and affective aspects.}

\section{- Affective aspect:}

I was excited by the vast amount of knowledge around me. I felt sad because I could never possess all that knowledge. There is always a feeling of awe and excitement. A feeling of curiousity. Being surrounded by lots of books motivates us to broaden our horizons.

After the explanations about how to locate a book, the part of my mind that had been anxious "went to sleep", and the part of my mind that was curious and thirsty for knowledge went into action. I felt a little confused, and it took me a while to become orientated. 


\section{- Cognitive aspect:}

We were exposed to a wide knowledge resource. I gained independence. The knowledge resources are organized in a logical and convenient manner. As knowledge consumers we need to know how knowledge is organized to help access it. The library visit helped us understand the importance of logical classification of publications. I understood the different functions of the librarian.

The visit was purpose directed to access resources related to our studies. The visit was effective. We quickly learnt to find our way between books and shelves. The explanation about using the Library internet site was clear, concise and enjoyable. The virtual tour of the library site was very useful.

The library visit changed my view point (and I believe others' too). I felt that I gained a view of the library as a place where many different activities take place.

\section{- Social aspect:}

The clear behavior code (no food, no cellphones, no bags) regulates our behavior in the library. The library is a place for students to meet and share knowledge. Work together in the study corners.

The activity promoted sharing and cooperation and helped us become better acquainted with each other. The out of class activity contributed to group spirit. There was some competition.

The library staff provides help when needed.

\section{Recommend an activity}

Suggest an experiential activity for a tour of the academic library that will help students understand the organization of knowledge resources in the library and ways of accessing and retrieving a required item.

Following are some of the suggested activities:

- Organize a competition within the library, unaided by the librarian: Require students to search for information on a certain topic using different resources (a web search, recent journals and textbooks).

- One group finds required books and the other group puts them back on the shelves. After the activity the groups share information about difficulties and insights.

- Create a Virtual Reality "Book Hunt" game in which the students have to retrieve a required resource within a limited time span by overcoming different obstacles.

\section{Visiting a Public Library}

Following the tour of the academic library, the students are required to select a public library of their choice, prepare a short interview with the librarian, visit the library and carry out the interview and write a report. The proposed interview questions are placed in an open forum for peerreview. A class discussion is held guiding students away from "yes-no" type questions to a more conversational style. Special attention is given to positive, polite attitudes rather than crude statements like "Aren't librarians obsolete in the age of the Internet?"

Once a well-formulated interview is ready, the students go ahead with their interview assignment. The completed reports are submitted in an open forum to enable knowledge sharing. No more that two teams are allowed to visit the same library. 
The completed reports vary considerably in length and richness. Some teams include photographs of the library layout (shelves, computer facilities, reading corners) and comments concerning the extent function and form are integrated harmoniously. The interview questions focus on the librarian's functions and vision of the impact of the information age on library readers and required services.

\section{Summary of Library Visit Reports}

During the past 3 years our students have handed in over 50 reports of team visits to over 30 libraries. The visited establishments ranged from central, "flagship" libraries with a large and varied reader population, to small neighborhood libraries in less fashionable city areas and small establishments in rural settlements. The central libraries were housed in purpose designed, architectural edifices, while the smaller establishments were often housed in schools or community centers. Some of the buildings also held small art galleries or memorial rooms.

The reports presented the library as a community focus. A "literature cabaret", with many activities for special reader groups, especially the young readers. The books and journals were often divided into several sections serving particular reader groups (children, students, adult fiction). The students reported on the different functions performed by the librarians, on the level of computer availability and internet access and on the librarian's comments concerning changes in her work since the introduction of ICT tools. Some reports described libraries in a state of crisis due to dwindling reader numbers and withdrawal of financial support by the local authority. Students commented that they had enjoyed the assignment and the opportunity to visit a new place or revisit a library of their childhood.

\section{Concluding Remarks}

I have described the general structure of the Academic Literacy course for students of the Instructional Systems' Technologies department. The reading material selection is relevant to the students' other courses and the specific course content and activities open a window into the unfamiliar terrain of academic publications and develop required information retrieval skills.

The "Book Hunt in the Library" and the "Library visit and Interview" out-of-class activities help students construct a general view of knowledge resources available to the public and to academics and bring the "archaic" library into the framework of modern information resources.

The students' responses, reports and comments show that the activities are well-received and provide emotional, cognitive and social impact.

\section{References}

Burke, J. (1985). The day the universe changed. (Hebrew translation, 1988) Tel Aviv, Israel: Ma'ariv Book Guild.

Eshet, Y. (2004). Digital literacy: A conceptual framework for survival skills in the digital era. Journal of Educational Multimedia and Hypermedia, 13 (1), 93-106

Henderson, L., Klemes, J. \& Eshet, Y. (2000). Just Playing a Game? Educational Simulation Software and Cognitive Outcomes. Journal of Educational Computing Research, 22 (1), 105 - 129.

Pearson, M. \& Somekh, B. (2003). Concept-Mapping as a research tool: a study of primary children's representations of information and communication technologies (ICT). Education and Information Technologies, 8(1), 5-22.

Ronen, M. \& Eliahu, M. (1997). Addressing students' common difficulties in basic electricity by qualitative simulation-based activities. Science Education, 32 (6), 392-399 
Salomon, G. (2000). Education and technology in the age of information. Haifa and Tel Aviv: Haifa University Publishers and Zmora-Bitan

Sims, R. (1995). Interactivity: A Forgotten Art? Retrieved 9 March 2007 from http://intro.base.org/docs/interact/

\section{Biography}

Dorothy Langley, PhD is a member of the Department of Instructional Systems' Technologies at the Holon Institute of Technology and a member of the Physics group at the Department of Science Teaching at the Weizmann Institute of Science, Rehovot, Israel.

She graduated in Physics from the Tel-Aviv University and received her PhD in Science Education from the Weizmann Institute of Science in 2001. Her research focuses on student learning in information technology based environments with a special interest in inquiry activities, teacher education and science teaching.

For the past 3 years she has taught courses in Academic Literacy, Research Methods, and Assessment of Educational Achievements in the Department of Instructional Systems' Technologies. This department offers courses covering 3 domains: Learning and Instruction in the Information Age, Information Systems and Information Design and Principles and Tools of Interactive Multimedia. These courses provide knowledge and skills that will be useful for the graduates in their chosen field of Training Management and Delivery. 